\title{
Purification of an antibacterial compound from Lantana lilacina
}

\author{
Aline C. Pereira, ${ }^{1}$ Hudson W. P. Carvalho, ${ }^{1}$ Geraldo H. Silva, ${ }^{2}$ Denilson F. Oliveira, ${ }^{* 1}$ \\ Henrique C. P. Figueiredo, ${ }^{3}$ Alberto J. Cavalheiro, ${ }^{2}$ Douglas A. Carvalho ${ }^{4}$ \\ ${ }^{1}$ Departamento de Química, Universidade Federal de Lavras, Caixa Postal 3037, \\ 37200-000 Lavras-MG, Brazil, \\ ${ }_{2}^{2}$ Instituto de Química, Universidade Estadual Paulista, Caixa Postal 35, 14801-970 \\ Araraquara-SP, Brazil, \\ ${ }^{3}$ Departamento de Medicina Veterinária, Universidade Federal de Lavras, Caixa Postal 3037, 37200-00 \\ Lavras-MG, Brazil, \\ ${ }^{4}$ Departamento de Biologia, Universidade Federal de Lavras, Caixa Postal 3037, 37200-000 Lavras-MG, Brazil
}

\begin{abstract}
RESUMO: "Purificação de um composto antibacteriano de Lantana lilacina". Observou-se, em estudo preliminar, que o extrato metanólico das folhas de L. lilacina, coletadas no município de Lavras (MG, Brasil), apresentava atividade antibacteriana. Em decorrência, buscou-se purificar e identificar a substância responsável por tal efeito, através de fracionamento do referido extrato direcionado por testes de difusão em agar com Aeromonas hydrophila, Bacillus subtilis, Pseudomonas aeruginosa e Staphylococcus aureus. Após partições com solventes e vários processos cromatográficos, isolou-se o [ $\beta$-3,4-diidroxifenil)etil]-(3'- $O$ - $\alpha$-L-ramnopiranosil)-(4'-O-cafeoil)$\beta$-D-glicopiranosídeo, que é conhecido como acteosídeo. A concentração inibitória mínima e a concentração bactericida mínima desta substância para A. hydrophila, B. subtilis, P. aeruginosa e $S$. aureus foram de $0,12,1,00,1,00$ e $0,25 \mathrm{mg} / \mathrm{mL}$, respectivamente.
\end{abstract}

Unitermos: Lantana lilacina, Verbenaceae, atividade antibacteriana, acteosídeo.

\begin{abstract}
Since the methanol extract of Lantana lilacina leaves collected in the city of Lavras (MG, Brazil) showed antibacterial properties in a preliminary study, a fractionation process guided by agar diffusion assays with Aeromonas hydrophila, Bacillus subtilis, Pseudomonas aeruginosa and Staphylococcus aureus was carried out to purify and identify the active compounds. After solvent partition and several chromatographic steps, [ $\beta$-3,4-dihydroxyphenyl)-ethyl]-(3'-O- $\alpha-\mathrm{L}-$ rhamnopyranosyl)-(4'-O-cafeoyl)- $\beta$-D-glycopyranoside, known as acteoside, was isolated. The minimal inhibition concentration and the minimal bactericidal concentration of such substance against $A$. hydrophila, B. subtilis, P. aeruginosa and $S$. aureus were $0.12,1.00,1.00$ and $0.25 \mathrm{mg} /$ $\mathrm{mL}$, respectively.
\end{abstract}

Keywords: Lantana lilacina, Verbenaceae, antibacterial activity, acteoside.

\section{INTRODUCTION}

Although pharmaceutical industries have produced a large number of new antimicrobial agents, the emergence of resistant bacterial strains has become a public health problem all over the world. In the United States of America, for instance, each year, $70 \%$ of the two million cases of bacterial infections acquired in hospitals consist of strains resistant to at least one antibacterial compound (Alexandria, 2004). Moreover, adverse effects and the high cost of the antimicrobial substances make the search for new effective drugs extremely necessary.

As the biological activity of plants has been known since antiquity (Rios and Recio, 2005), a preliminary evaluation of local plant extracts was carried out to identify those with antimicrobial properties (Oliveira et al., 2007). During such study, a pronounced in vitro antibacterial property was observed for the aerial parts of Lantana lilacina Desf. (Verbenaceae), a 50-120 $\mathrm{cm}$ height native Brazilian shrub, which produces pink or purple flowers. Known as a weed and an ornamental plant (Lorenzi, 2000), it has been used in the traditional medicine to treat cold and bronchitis (Balbach, 1986). Although several substances have been identified in other species of the Lantana genus (Begum et al., 2000; Siddiqui et al., 1995; Barbosa-Filho et al., 2006), only monoterpene glucoside esters were isolated from $L$. lilacina leaves (Dembitsky, 2004). No further studies concerning the chemical composition of this plant species have been found. Therefore, this research was aimed to purify and identify the antibacterial compounds present in the methanol extract of L. lilacina leaves.

\section{MATERIAL AND METHODS}




\section{Plant material}

Leaves from Lantana lilacina Desf. (Verbenaceae) were collected in the city of Lavras, State of Minas Gerais (Brazil). Voucher specimens were identified by Prof. Valéria E. G. Rodrigues and deposited in the Herbarium ESAL (ESAL 15.172), at Universidade Federal de Lavras, Lavras.

\section{General experimental procedures}

All reagents used were of recognized analytical grade. Acetic acid, acetonitrile, and methanol were HPLC-grade (Vetec, Brazil). During the purification steps, solvent concentration was carried out in a rotatory evaporator at $35^{\circ} \mathrm{C}$, followed by $24 \mathrm{~h}$ in a freeze-drier. Except when mentioned otherwise, all fractions were submitted to antibacterial diffusion assays to direct purification. Column chromatography was carried out on silica gel 60 (230-400 mesh, Merck). Mass spectra were obtained on an Agilent 1100 LC/MS Trap equipped with an electrospray interface. Samples (1.0 $\mathrm{mg})$ were dissolved in $\mathrm{MeOH}(1.0 \mathrm{~mL})$ and $20 \mu \mathrm{L}$ were directly injected into the interface at a flow rate of $5 \mu \mathrm{L} /$ min. Deuterated dimethylsulphoxide (DMSO-do) and deuterated methanol ( $\left.\mathrm{CD}_{3} \mathrm{OD}\right)$ were used as solvents for nuclear magnetic resonance (NMR) analyses performed on a Varian Unit 500 instrument using solvent peak as reference. ${ }^{1} \mathrm{H}$ and ${ }^{13} \mathrm{C}$ NMR spectra were obtained in both solvents, while HMBC, HMQC and TOCSY analyses were carried out only in DMSO-d6.

\section{Extraction and isolation}

Fresh leaves of L. lilacina were exhaustively extracted with methanol at room temperature. Part of the crude extract $(0.5 \mathrm{mg})$ was dissolved in $0.5 \mathrm{~mL}$ of an ethanol: $\mathrm{H}_{2} \mathrm{O}(7: 3 ; \mathrm{v} / \mathrm{v})$ solution and submitted to the antibacterial diffusion assay. Another part $(0.5 \mathrm{mg})$ of such extract was dissolved in $0.5 \mathrm{~mL}$ of an aqueous $1 \%(\mathrm{~g} / \mathrm{mL})$ Tween 80 solution and used in the broth microdilution assay.

The crude extract (10.0 g) was subsequently washed with hexane $(10 \times 100 \mathrm{~mL})$, ethyl acetate (AcOEt; $10 \times 100 \mathrm{~mL})$ and methanol (MeOH; $10 \times 100 \mathrm{~mL})$. Part (3.5 g) of the $\mathrm{MeOH}$ fraction (M1) was successively eluted with $\mathrm{MeOH}, \mathrm{H}_{2} \mathrm{O}$ and $\mathrm{HCl} 0.1 \mathrm{M}$ through a silica gel column $(4 \times 15 \mathrm{~cm})$. Part $(1.8 \mathrm{~g})$ of the resulting $\mathrm{MeOH}$ fraction (M2) was eluted with $\mathrm{MeOH}$ through a C-18 column (1 x $5 \mathrm{~cm})$, yielding fraction M3 (1.0 g). Then, M3 was fractionated on a C-18 column (Luna $\mathrm{C}-18,200 \times 21.2 \mathrm{~mm}, 10 \mu \mathrm{M}$, Phenomenex, USA), using aqueous $0.1 \%$ acetic acid solution: $\mathrm{MeOH}(5 \%$ $\mathrm{MeOH}$ during $5 \mathrm{~min}, 5-100 \% \mathrm{MeOH}$ during $60 \mathrm{~min}$, $100 \% \mathrm{MeOH}$ for $21 \mathrm{~min}$ ), at a flow rate of $30 \mathrm{~mL} / \mathrm{min}$, as eluent. An UV detector set at $254 \mathrm{~nm}$ was employed to monitor the fractionation. One of the resulting fractions
(F11; $169 \mathrm{mg}$; eluted between 18-19 min) was purified on the same column employing aqueous $0.1 \%$ acetic acid solution: $\mathrm{MeOH}(62: 38)$ as eluent, at a flow rate of $20 \mathrm{~mL} /$ min. In this case the UV detector was set at $320 \mathrm{~nm}$. This procedure yielded fraction 6 as a pure compound (F6; 15 $\mathrm{mg}$; eluted between 10.2-12.5 min), which was identified as acteoside (Figure 1) by NMR and mass spectrometry analyses.

\section{Antibacterial assays}

Antibacterial activity was evaluated with four standard bacterial strains acquired from the American Type of Culture Collection (ATCC, USA): Bacillus subtilis ATCC 6633 and Staphylococcus aureus ATCC 25923 (Gram-positive), Aeromonas hydrophila ATCC 7966 and Pseudomonas aeruginosa ATCC 27853 (Gramnegative). Agar diffusion assays (NCCLS, 2003a) were carried out in duplicates. Briefly, after bacterial growth in triptic soy agar (TSA, Acumedia, USA) during $24 \mathrm{~h}$ at $37^{\circ} \mathrm{C}$, the resulting cultures were used to prepare cell suspensions in an aqueous $0.85 \%(\mathrm{~g} / \mathrm{mL}) \mathrm{NaCl}$ solution, at 0.5 turbidity according to MacFarland scale. Such suspensions were inoculated with a swab on the surface of Mueller-Hinton agar (Merck, Germany) Petri dishes and $40 \mu \mathrm{L}$ of each sample were deposited into $6 \mathrm{~mm}$ diameter holes made on the inoculated medium. After 24 $\mathrm{h}$ at $37^{\circ} \mathrm{C}$, samples causing $7 \mathrm{~mm}$ or larger inhibition zone diameters around the holes were considered active.

Minimal inhibitory and minimal bactericidal concentrations (MIC and $\mathrm{MBC}$ ) were determined by a broth microdilution assay (NCCLS, 2003b). A twofold serial dilution of the reference (chloramphenicol succinate: Sigma, USA; $400 \mu \mathrm{g} / \mathrm{mL}$ ) and samples were prepared using Mueller-Hinton broth (MHB: Biolife, Italy) supplemented with calcium and magnesium cations (Alderman and Smith, 2001). The crude extract was dissolved in an aqueous $1 \%(\mathrm{~g} / \mathrm{mL})$ Tween 80 solution at a concentration of $10 \mathrm{mg} / \mathrm{mL}$ and filtered through a $0.22 \mu \mathrm{m}$ membrane (GV Durapore PVDF, Milipore, USA). $7.5 \times 10^{4} \mathrm{CFU}$ were poured into each well and the initial extract concentration was $5.0 \mathrm{mg} / \mathrm{mL}$. Aqueous $1 \%$ Tween 80 and chloramphenicol solutions were employed as negative and positive control, respectively. After 24 h at $37{ }^{\circ} \mathrm{C}, 10 \mu \mathrm{L}$ were withdrawn from each well with no bacterial growth and subcultured in TSA during $24 \mathrm{~h}$ at the same temperature. MIC was considered the lowest concentration of the extract that prevented visible growth in the well during $24 \mathrm{~h}$ and MBC was defined as the lowest concentration yielding negative subcultures during $24 \mathrm{~h}$. The isolated compound (acteoside, Figure 1) was also submitted to a broth microdilution assay. It (2 $\mathrm{mg}$ ) was dissolved in $100 \mu \mathrm{L}$ of DMSO (P.A.) and diluted with MHB. The highest acteoside's concentration in the well was $1.0 \mathrm{mg} / \mathrm{mL}$.

\section{RESULTS AND DISCUSSION}


As preliminarily observed (Oliveira et al., 2007), L. lilacina methanol extract was able to inhibit the growth of Gram-positive and Gram-negative bacteria strains (Table 1).

During all purification steps, only one active fraction was observed. Consequently, it seems that the antibacterial property of the crude extract was due only to the isolated substance, which amounted to $15 \mathrm{mg}$ of a hygroscopic viscous oil that could get dark easily when exposed to light and air. In the ${ }^{1} \mathrm{H}$ NMR spectrum (Table 2 ), obtained in DMSO- $d 6$, it was clear that most signals belonged to groups linked to heteroatoms $(2.7-5.0 \mathrm{ppm})$ or unsaturated carbons (6.2-7.5 ppm). Such result suggested aromatic rings linked to carbohydrate units. The ${ }^{13} \mathrm{C}$ NMR spectrum (Table 2) pointed to the same direction,

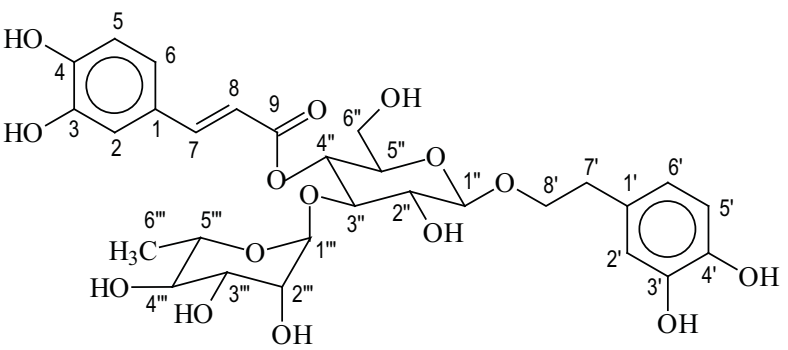

Figure 1. Structure of the acteoside.

since most signals were in the carbon $\mathrm{sp}^{3}$-heteroatom and carbon $\mathrm{sp}^{2}$ regions. Signals at 140 and $150 \mathrm{ppm}$ suggested carbon $\mathrm{sp}^{2}$ - heteroatom groups, while the one at 165 ppm seemed due to a carbonyl group, probably an ester (Silverstein and Webster, 1998; Pretsch et al., 1989). The

Table 1. Inhibition zone diameter (IZD), minimal inhibitory concentration (MIC) and minimal bactericidal concentration (MBC) for the crude methanol extract of Lantana lilacina aerial part: (-) no inhibition zone; (x) not performed.

\begin{tabular}{|c|c|c|c|c|}
\hline Crude extract & A. hydrophila & B. subtilis & P. aeruginosa & S. aureus \\
\hline IZD (mm) & 12.5 & 10.0 & - & 8.0 \\
\hline $\mathrm{MIC}(\mathrm{mg} / \mathrm{mL})$ & 1.25 & 1.25 & $\mathrm{x}$ & 0.62 \\
\hline $\mathrm{MBC}(\mathrm{mg} / \mathrm{mL})$ & 1.25 & 1.25 & $\mathrm{x}$ & 2.50 \\
\hline
\end{tabular}

Table 2. ${ }^{13} \mathrm{C}$ - and ${ }^{1} \mathrm{H}$ - NMR data for the isolated compound (acteoside) in DMSO- $d 6$ and $\mathrm{CD}_{3} \mathrm{OD}$ : $\delta$ ppm (mult; $J=\mathrm{Hz} ; \mathrm{H}$ ).

\begin{tabular}{|c|c|c|c|c|}
\hline \multirow[t]{2}{*}{ Position } & \multicolumn{2}{|c|}{${ }^{13} \mathrm{C} ; 125 \mathrm{MHz}$} & \multicolumn{2}{|c|}{${ }^{1} \mathrm{H} ; 500 \mathrm{MHz}$} \\
\hline & DMSO-d6 & $\mathrm{CD}_{3} \mathrm{OD}$ & DMSO-d6 & $\mathrm{CD}_{3} \mathrm{OD}$ \\
\hline 1 & 125.8 & 126.5 & & \\
\hline 2 & 114.6 & 114.1 & $7.08(1 \mathrm{~s} ; 1 \mathrm{H})$ & $7.05(\mathrm{~d} ; J=2.0 ; 1 \mathrm{H})$ \\
\hline 3 & 145.5 & 146.8 & & \\
\hline 4 & 148.4 & 149.2 & & \\
\hline 5 & 113.9 & 115.9 & $6.82(\mathrm{~d} ; J=8.2 ; 1 \mathrm{H})$ & $6.77(\mathrm{~d} ; J=8.1 ; 1 \mathrm{H}))$ \\
\hline 6 & 121.3 & 122.0 & $7.03\left(\mathrm{dd} ; J_{1}=8.2 ; J_{2}=1.5 ; 1 \mathrm{H}\right)$ & $6.95\left(\mathrm{dd} ; J_{1}=8.1 ; J_{2}=2.0 ; 1 \mathrm{H}\right)$ \\
\hline 7 & 145.5 & 148.5 & $7.51(\mathrm{~d} ; J=16.0 ; 1 \mathrm{H})$ & $7.58(\mathrm{~d} ; J=16.0 ; 1 \mathrm{H})$ \\
\hline 8 & 113.5 & 115.1 & $6.25(\mathrm{~d} ; J=16.0 ; 1 \mathrm{H})$ & $6.26(\mathrm{~d} ; J=16.0 ; 1 \mathrm{H})$ \\
\hline 9 & 165.5 & 167.1 & & \\
\hline 1 , & 129.6 & 130.3 & & \\
\hline 2 ' & 116.2 & 115.3 & $6.68(1 \mathrm{~s} ; 1 \mathrm{H})$ & $6.69(\mathrm{~d} ; J=2.0 ; 1 \mathrm{H})$ \\
\hline 3 , & 144.9 & 145.9 & & \\
\hline 4 ' & 143.5 & 145.6 & & \\
\hline 5 , & 115.5 & 115.3 & $6.69(\mathrm{~d} ; J=6.5 ; 1 \mathrm{H})$ & $6.67(\mathrm{~d} ; J=8.3 ; 1 \mathrm{H})$ \\
\hline 6 ' & 119.5 & 120.0 & $6.55\left(\mathrm{dd} ; J_{1}=6.5 ; J_{2}=1.5 ; 1 \mathrm{H}\right)$ & $6.56\left(\mathrm{dd} ; J_{1}=8.3 ; J_{2}=2.0 ; 1 \mathrm{H}\right)$ \\
\hline 7 ' & 34.9 & 35.3 & $\begin{array}{l}2.78\left(\mathrm{ddd} ; J_{1}=13.0 ; J_{2}=J_{3}=7.5 ; 1 \mathrm{H}\right) \\
2.73\left(\mathrm{dd} ; J_{1}=13.0 ; J_{2}=7.5 ; 1 \mathrm{H}\right)\end{array}$ & $2.79(\mathrm{~m} ; 2 \mathrm{H})$ \\
\hline 8 & 70.2 & 72.3 & $\begin{array}{l}3.94\left(\mathrm{ddd} ; J_{1}=J_{2}=7.5 ; J_{3}=9.1 ; 1 \mathrm{H}\right) \\
3.66\left(\mathrm{ddd} ; J_{1}=7.5 ; J_{2}=J_{3}=9.1 ; 1 \mathrm{H}\right)\end{array}$ & $\begin{array}{l}4.03\left(\mathrm{dd} ; J_{1}=7.5 ; J_{2}=13.0 ; 1 \mathrm{H}\right) \\
3.72\left(\mathrm{dd} ; J_{1}=9.5 ; J_{2}=13.0 ; 1 \mathrm{H}\right)\end{array}$ \\
\hline $1 "$, & 102.2 & 101.8 & $4.41(\mathrm{~d} ; J=8.0 ; 1 \mathrm{H})$ & $4.37(\mathrm{~d} ; J=8.0 ; 1 \mathrm{H})$ \\
\hline $2^{\prime \prime}$ & 74.4 & 75.0 & $3.27\left(\mathrm{dd} ; J_{1}=J_{2}=8.5 ; 1 \mathrm{H}\right)$ & $3.38\left(\mathrm{dd} ; J_{1}=8.0 ; J_{2}=7.7 ; 1 \mathrm{H}\right)$ \\
\hline $3 "$ & 79.6 & 80.4 & $3.76\left(\mathrm{dd} ; J_{1}=J_{2}=8.5 ; 1 \mathrm{H}\right)$ & $3.81\left(\mathrm{dd} ; J_{1}=7.7 ; J_{2}=9.3 ; 1 \mathrm{H}\right)$ \\
\hline 4 ", & 69.1 & 70.9 & $4.77\left(\mathrm{dd} ; J_{1}=J_{2}=8.5 ; 1 \mathrm{H}\right)$ & $4.90\left(\mathrm{dd} ; J_{1}=6.0 ; J_{2}=9.3 ; 1 \mathrm{H}\right)$ \\
\hline 5, & 74.4 & 74.8 & $3.53(\mathrm{~m})$ & $3.53(\mathrm{~m} ; 1 \mathrm{H})$ \\
\hline 6, & 61.0 & 61.2 & $3.47(\mathrm{~m} ; 1 \mathrm{H})$ & $3.62(\mathrm{~m} ; 1 \mathrm{H})$ \\
\hline & & & $3.36(\mathrm{~m} ; 1 \mathrm{H})$ & $3.52(\mathrm{~m} ; 1 \mathrm{H})$ \\
\hline $1,$, & 101.1 & 103.0 & $5.09(\mathrm{~s} ; 1 \mathrm{H})$ & $5.18(\mathrm{~d} ; J=1.5 ; 1 \mathrm{H})$ \\
\hline $2^{\prime \prime}$, & 70.3 & 71.1 & $3.74(\mathrm{~s} ; 1 \mathrm{H})$ & $3.91(\mathrm{~m} ; 1 \mathrm{H})$ \\
\hline $3^{\prime \prime \prime}$ & 70.4 & 71.0 & $3.30-3.58(\mathrm{~m} ; 1 \mathrm{H})$ & $3.55(\mathrm{~m} ; 1 \mathrm{H})$ \\
\hline $4, "$ & 72.0 & 72.6 & $3.16\left(\mathrm{dd} ; J_{1}=9.0 ; J_{2}=9.5 ; 1 \mathrm{H}\right)$ & $3.27(\mathrm{~m} ; 1 \mathrm{H})$ \\
\hline 5, & 68.8 & 69.2 & $3.32(\mathrm{~m} ; 1 \mathrm{H})$ & $3.54(\mathrm{~m} ; 1 \mathrm{H})$ \\
\hline $6^{\prime \prime}$, & 18.1 & 17.2 & $1.01(\mathrm{~d} ; J=6.5 ; 3 \mathrm{H})$ & $1.08(\mathrm{~d} ; J=6.0 ; 3 \mathrm{H})$ \\
\hline
\end{tabular}


Table 3. Minimal inhibitory concentration (MIC) and minimal bactericidal concentration (MBC) of acteoside and chloramphenicol: Values in $\mathrm{mg} / \mathrm{mL}$; $(\mathrm{x})$ not performed.

\begin{tabular}{|c|c|c|c|c|c|c|c|c|c|}
\hline \multirow[t]{2}{*}{ Substance } & \multicolumn{2}{|c|}{ A. hydrophila } & \multicolumn{2}{|c|}{ B. subtilis } & \multicolumn{2}{|c|}{ P. aeruginosa } & \multicolumn{3}{|c|}{ S. aureus } \\
\hline & MIC & $\mathrm{MBC}$ & MIC & MBC & MIC & $\mathrm{MBC}$ & & MIC & $\mathrm{MBC}$ \\
\hline Acteoside & 0.12 & 0.12 & $>1.00$ & $\mathrm{x}$ & 1.00 & 1.00 & 0.25 & & 0.25 \\
\hline Chloramphenicol & 0.02 & 0.05 & 0.10 & 0.10 & $>0.20$ & $\mathrm{x}$ & 0.20 & & $>0.20$ \\
\hline
\end{tabular}

interpretation of TOCSY $1 \mathrm{D},{ }^{1} \mathrm{H}$ and ${ }^{13} \mathrm{C}$ NMR spectra, as well as heteronuclear correlations at short (HMQC) and long distances (HMBC), permitted to attribute the structure of the [ $\beta$-3,4-dihydroxyphenyl)-ethyl](3'-O- $\alpha$-L-rhamnopyranosyl)-(4'-O-cafeoyl)- $\beta$-Dglycopyranoside, known as acteoside or verbascoside (Figure 1), to the isolated compound. It is worth to mention that the stereochemistry of the caffeoyl moiety was clear in the ${ }^{1} \mathrm{H}$ spectrum, since the coupling constant $(J)$ between $\mathrm{H} 7$ and $\mathrm{H} 8$ was $16 \mathrm{~Hz}$, which is characteristic of a trans arrangement (Silverstein and Webster, 1998)

Although the spectra obtained in DMSO- $d 6$ were in accordance with NMR data reported for the acteoside dissolved in the same solvent (Tanaka et al., 2004), $\mathrm{CD}_{3} \mathrm{OD}$ was also used, since it could afford a simpler ${ }^{1} \mathrm{H}$ NMR spectrum. As a consequence, the $\alpha$-L-rhamnose moiety with OR (linked to C1"') and OH (linked to C2"') in the axial positions was confirmed by the low $J$ between $\mathrm{H} 1$ " ' and $\mathrm{H} 2$ " ( $J=1.5 \mathrm{~Hz}$, equatorial-equatorial). In the $\beta$-D-glucose unit, the trans-diaxial couplings (6.0 - 9.3 $\mathrm{Hz}$ ) became clear for all hydrogen atoms linked to the ring. Moreover, NMR spectra obtained in $\mathrm{CD}_{3} \mathrm{OD}$ were totally in agreement with the findings of Wu et al. (2004) and Owen et al. (2003) for the acteoside.

The mass spectrometry analysis of the isolated compound in the negative mode showed peaks at $\mathrm{m} / \mathrm{z} 623$ $[\mathrm{M}-\mathrm{H}]^{-}$and $659[\mathrm{M}+\mathrm{Cl}]^{-}$. Experiments inducing $\mathrm{m} / z 623$ to fragmentation resulted in $m / z 461$ [M-H-162] ${ }^{-}\left(\mathrm{MS}^{2}\right)$ and $m / z 315$ [M-H-162-146] ${ }^{-}\left(\mathrm{MS}^{3}\right)$, corresponding to caffeoyl and rhamnose units loss, respectively. In the positive mode, as observed by Plaza et al. (2005), peaks were detected at $m / z 647[\mathrm{M}+\mathrm{Na}]^{+}$and $501[\mathrm{M}+\mathrm{Na}-146]^{+}$ $\left(\mathrm{MS}^{2}\right)$, which was due to the rhamnose unit loss.

Once there was no doubt that the isolated compound was the acteoside, a microdilution assay was carried out to evaluate its antimicrobial activity. Specifically with $A$. hydrophila and S. aureus, MIC and MBC values were very close to those obtained with chloramphenicol (Table 3). These results are in agreement with those reported by Didry et al (1999), who observed Proteus mirabilis and $S$. aureus growth inhibition by the acteoside at $0.128 \mathrm{mg} / \mathrm{mL}$, during an agar dilution assay. Similarly, Lima et al. (2003) observed that a mixture of acteoside and isoacteoside showed MIC of $0.6 \mathrm{mg} / \mathrm{mL}$ against $S$. aureus and B. subtilis. According to Avila et al. (1999), acteoside inhibits $S$. aureus leucine admission, which stops protein synthesis and kills such bacterium. Unfortunately, $P$. aeruginosa, a bacterium resistant to several drugs (Barros, 2001), was able to grow in the presence of L. lilacina crude extract. Moreover, acteoside's MIC and MBC against this microorganism were both $1 \mathrm{mg} / \mathrm{mL}$, which is a high value when compared to other substances ( $\mathrm{Ng}$ et al., 1996; Ogundipe et al., 2001; Lima et al., 2003).

It is worth to mention that other biological activities have also been attributed to acteoside: protein kinase C inhibitor (Herbert et al.,1991); antitumor and immunosuppressive (Zhang et al., 2002; Ohno et al., 2002); antioxidant (Ono et al., 2005; Owen et al., 2003; Aligiannia et al., 2003); and antiinflammatory (Diaz et al., 2004).

In conclusion, for the first time it is shown that the antibacterial activity of L. lilacina leaves methanol extract is due to the presence of acteoside, a compound largely distributed in the plant kingdom. As observed in this study and by other research groups, such substance should be better evaluated by pharmacological and chemical assays aiming at the pharmaceutical use, either in humans or animals.

\section{ACKNOWLEDGMENTS}

The authors gratefully acknowledge Fundação de Amparo à Pesquisa do Estado de Minas Gerais (FAPEMIG), Conselho Nacional de Desenvolvimento Científico e Tecnológico (CNPq) and Coordenação de Aperfeiçoamento de Pessoal de Nível Superior (CAPES) for financial support and fellowships.

\section{REFERENCES}

Alderman DJ, Smith P 2001. Development of draft protocols of standard reference methods for antimicrobial agent susceptibility testing of bacteria associated with fish diseases. Aquaculture 196: 211-243.

Alexandria VA 2005. Statement of the Infectious Disease Society of America (IDSA) concerning 'Bioshield II: Responding to an ever-changing threat'. IDSA, apud microbial activity of flavonoids. Int $J$ Antimicrob Agents 26: 343-356.

Aligiannia N, Mikatu S, Tsardis ET, Harvala C, Tsarknis I, Lalas S, Haroutounian S 2003. Methanolic extract of Verbascum macrurum as a source of natural preservatives against oxidative rancidity. J Agric Food Chem 51: 7308-7312.

Avila JG, Liverant JG, Martynez A, Martynez G, Munoz JL, Arciniegas A, De Vivar AR 1999. Mode of action of Buddleja cordata verbascoside against Staphylococcus aureus. J Ethnopharmacol 66: 75-78.

Balbach A 1986. As plantas curam. Itaquaquecetuba (SP): Edel.

Barbosa-Filho JM, Medeiros KCP, Diniz MFFM, Batista LM, 
Athayde-Filho PF, Silva MS, Cunha EVL, Almeida JRGS, Quintans-Júnior LJ 2006. Natural products inhibitors of the enzyme acetylcholinesterase. Rev Bras Farmacogn 16: 258-285.

Barros E 2001. Antimicrobianos: consulta rápida. Porto Alegre (RS): Artmed.

Begum S, Wahab A, Siddiqui BS, Qamar F 2000. Nematicidal constituents of the aerial parts of Lantana camara. $J$ Nat Prod 63: 765-767.

Dembitsky VM 2004. Chemistry and biodiversity of the biologically active natural glycosides. Chem Biodiversity 1: 673.

Diaz AM, Abad MJ, Fernandez L, Silvan AM, De Santos J, Bermejo P 2004. Phenylpropanoid glycosides from Scrophularia scorodonia: in vitro anti-inflammatory activity. Life Sci 74: 2515-2526.

Didry N, Seidel V, Dubreuil L, Tillequin F, Bailleul F 1999. Isolation and antibacterial activity of phenylpropanoid derivatives from Ballota nigra. J Ethnopharmacol 67: 197-202.

Herbert JM, Maffrand JP, Taoubi K, Augereau JM, Fouraste I, Gleye J 1991. Verbascoside isolated from Lantana camara, an inhibitor of protein kinase C. J Nat Prod 54: $1595-1600$.

Lima CSA, Amorim ELC, Fonseca KX, Ribeiro S, Chiappeta AA, Nunes XP, Agra MF, Cunha EVL, Silva MS, Barbosa-Filho JM 2003. Antimicrobial activity of a mixture of two isomeric phenylporpanoid glycosides from Arrabidaea Harleyi A.H. Gentry (Bignoniaceae). Rev Bras Cienc Farm 39: 77-81.

Lorenzi H 2000. Plantas daninhas do Brasil: terrestres, aquáticas, parasitas e tóxicas. Nova Odessa (SP): Instituto Plantarum.

NCCLS 2003a. Performance standards for antimicrobial disk susceptibility tests; approved standard. Wayne, Pennsylvania 23 (1) (document M2-A8).

NCCLS 2003b. Methods for dilution antimicrobial susceptibility tests for bacteria that grow aerobically; approved standard. Wayne, Pennsylvania 23 (2) (document M7-A6).

Ng TB, Ling JML, Wang ZT, Cai JN, Xu GJ 1996. Examination of coumarins, flavonoids and polysaccharopeptide for antibacterial activity. Gen Pharmac 27: 1237-1240.

Ogundipe OO, Moody JO, Houghton PJ, Odelola HA 2001. Bioactive chemical constituents from Alchornea laxiflora (Benth) Pax and Hoffman. J Ethnopharmacol 74: $275-280$.

Ohno T, Inoue M, Ogihara Y, Saracoglu I 2002. Antimetastic activity of acteoside, a phenylethanoid glycoside. Biol Pharm Bull 25: 666-668.

Oliveira DF, Pereira AC, Figueiredo HC, Carvalho DA, Silva G, Nunes AS, Alves DS, Carvalho HWP 2007. Antibacterial activity of plant extracts from Brazilian southeast region. Fitoterapia 78: 142-145.

Ono M, Morinaga H, Masuoka C, Ikeda T, Okawa M, Kinjo J, Nohara T 2005. New bisabolane-type sesquiterpenes from the aerial parts of Lippia dulcis. Chem Pharm Bull 53: 1175-1177.

Owen RW, Haubner R, Mier W, Giacosa A, Hull W, Spiegelhalder $\mathrm{B}$, Bartsch H 2003. Isolation structure elucidation and antioxidant potential of the major phenolic and flavonoid compounds in brined olive drupes. Food Chem Toxicol 41: 703-717.
Plaza A, Montoro P, Benavides A, Pizza C, Piacent S 2005. Phenylpropanoid glycosides from Tynanthus panurensis: caracterization and LC-MS quantitative analysis. J Agric Food Chem 53: 2853-2858.

Pretsch E, Clerc T, Seibl J, Simon W 1989. Spectral data for structure determination of organic compounds. Berlin: Springer-Verlag.

Rios JL, Recio MC 2005. Medicinal plants and antimicrobial activity. J Ethnopharmacol 100: 80-84.

Siddiqui BS, Raza SM, Begum S, Siddiqui S, Firdous S 1995. Pentacyclic triterpenoids from Lantana camara. Phytochemistry 38: 681-685.

Silverstein RM, Webster FX 1998. Spectrometric identification of organic compounds. New York: John Wiley \& Sons, Inc., 6th edition.

Tanaka T, Ikeda T, Kaku M, Zhu XH, Okawa M, Yokomizo K, Uyeda M, Nohara T 2004. A new lignan glycoside and phenyletanoid glycosides from Strobilanthes cusia Bremek. Chem Pharm Bull 52: 1242-1245.

Wu J, Huang JS, Xiao S, Zhang S, Xiao ZH, Long LJ, Huang LM 2004. Espectral assignments and reference data - Complete assignments of H-1 and C-13 NMR data for 10 phenylethanoid glycosides. Magn Reson Chem 42: 659-662.

Zhang F, Jia Z, Deng Z, Fan J, Chen J, Wu H, Zhao C, Wei Y 2002. Inhibition of verbascoside on the telomerase activity of human gastric adenocarcinoma cell MKN 45. Shiejie Huaren Xiaohua Zazhi 10: 366-367. 